\title{
EVALUATION OF QUALITY OF BUILDING MAINTENANCE IN AMPEL MOSQUE SURABAYA
}

\author{
Agung Sedayu \\ UIN Maulana Malik Ibrahim Malang \\ Jln.Gajayana 50 Malang, Jawa Timur, Indonesia \\ E-mail: uinsedayu@gmail.com
}

\begin{abstract}
The Ampel Mosque Surabaya East Java Indonesia is a historic mosque that became one of the centers of the spread of Islam in Java by Sunan Ampel. The mosque is a historic site to get attention in care and maintenance on the physical components of the building to prevent the occurrence of damage. This study aims to evaluate the quality of maintenance of Ampel Surabaya mosque building. This study considers social-culture aspects and technical aspects as an instrument to support building maintenance and reliability enhancement. The quality of the maintenance affects the reliability of mosque building construction. The evaluation is done by considering the user's perception of the facility to worship in the mosque of Ampel. The method used is Structural Equation Modeling (SEM). The result of the research shows four variables that make up the model namely: Structural Component, Architectural Component as exogenous manifest variable 2, Quality Maintenance, and Construction Reliability. Relationships between variables indicate a strong level of significance. The path diagram model obtained is explained that the variability of Maintenance Quality is explained by Structural Component and Architectural Component of $81.6 \%$, while Construction Reliability can be explained by Structural Component, Maintenance Quality, and Architectural Component variability of $87.2 \%$. It can be concluded that the influence relationship in the overall model is positive. Ampel mosque management can perform maintenance efforts of mosque building components based on evaluation results and models to calculate the quality of maintenance and reliability of mosque building construction.
\end{abstract}

\section{Keywords:}

Quality; maintenance; component; building; Ampel Mosque.

\begin{abstract}
Abstrak
penyebaran agama Islam di Jawa oleh Sunan Ampel. Masjid ini menjadi situs bersejarah perlu mendapat perhatian dalam perawatan dan pemeliharaan pada komponen fisik bangunannya untuk mencegah terjadinya kerusakan. Penelitian ini bertujuan untuk melakukan evaluasi kualitas pemeliharaan bangunan masjid Ampel Surabaya. Penelitian ini mempertimbangkan aspek sosial budaya dan teknis bangunan sebagai instrumen untuk menopang pemeliharaan dan keandalan bangunan. Kualitas pemeliharaan tersebut berpengaruh terhadap keandalan konstruksi bangunan masjid. Evaluasi dilakukan dengan mempertimbangkan persepsi pengguna yaitu jamaah masjid Ampel yang menggunakan fasilitas masjid untuk beribadah sehingga mengetahui perkembangan masjid. Metode yang digunakan adalah Structural Equation Modeling (SEM). Hasil penelitian memperoleh empat variabel yang menyusun model yaitu Komponen Struktural, Komponen Arsitektural sebagai variabel manifes eksogen 2, Kualitas Pemeliharaan, dan Keandalan Konstruksi. Hubungan antar variabel menunjukkan tingkat signifikansi yang kuat. Model diagram jalur yang diperoleh dijelaskan bahwa variabilitas Kualitas Pemeliharaan dijelaskan oleh Komponen Struktural dan Komponen Arsitektural sebesar 81,6 \%, sedangkan Keandalan Konstruksi yang dapat dijelaskan oleh variabilitas Komponen Struktural, Kualitas Pemeliharaan, dan Komponen Arsitektural sebesar 87,2 \%. Dapat disimpulkan bahwa hubungan pengaruh dalam model keseluruhan bernilai positif. Pengelola masjid Ampel dapat melakukan upaya pemeliharaan komponen bangunan masjid berdasarkan pada hasil evaluasi dan model untuk menghitung kualitas pemeliharaan dan keandalan konstruksi bangunan masjid..
\end{abstract}

Kata Kunci:

Kualitas; pemeliharaan; komponen; bangunan; masjid Ampel

DOI: $10.15575 /$ jw.v3i2.5781

Received: November 2019 ; Accepted: December 2019 ; Published: December 2019 


\section{A. INTRODUCTION}

The Ampel Mosque Surabaya East Java Indonesia is a historic mosque that became one of the centers of the spread of Islam in Java by Sunan Ampel. This mosque was founded by Sunan Ampel which is one of the wali (guardian) songo who plays a role in spreading Islam in Java. Ampel Mosque was founded in 1421 until now has experienced development in the physical building. The area of the mosque is also adjacent to the tomb of Sunan Ampel and family. Ampel Mosque is a historic site that breathes Islamic religion needs to get attention in care and maintenance on the physical components of the building to prevent the occurrence of damage and destruction. The well-preserved and elected Ampel Mosque will be historical religious wisdom and still serve as a center for Muslim worship, especially in Indonesia. Every day this mosque becomes crowded visited by people who make pilgrimage to the tomb of Sunan Ampel and worship in this mosque. This study aims to evaluate the quality of maintenance of Ampel Surabaya mosque building. This study considers social-culture aspects and technical aspects as an instrument to support building maintenance and reliability enhancement. The social-culture aspects are user perceptions and building components as the technical aspects of this research analysis. The user can assess the building maintenance that has an influence on construction reliability. The quality of the maintenance affects the reliability of mosque building construction. Mosque managers have made maintenance efforts until they need to be evaluated in order to determine the priority of components that are maintained or maintained intensively based on user perceptions. Mosque users who become respondents are pilgrims who often use the mosque as a place of worship so as to know the development of the mosque

\footnotetext{
${ }^{1}$ A. Sedayu dan S. Mangkoedihardjo, "Performance Evaluation of Housing Contractor by Applying The Principles of Environmentally Friendly Infrastructure," International Journal of Civil Engineering and Technology 9, no. 4 (2018): 0976-6316.

2 Agung Sedayu, "Performance Optimization Model of Hamid Rusdi Green Terminal in Malang," Journal of
}

both physically and non-physically. The comparison of this study with other previous studies is the existence of a novelty considering the perception of users in evaluating the quality of maintenance of the physical components of the mosque building. Besides, it also developed methods and variables of previous research adapted to the existing condition of Ampel mosque. Some of the research that is used as a reference in this research is the research conducted by Sedayu (2018) ${ }^{1}$ about service quality modeling for housing procurement project by green building principles. The research variables reviewed are assurance, responsibility and reliability, performance, aesthetics, easiness, durability, architectural design, and eco-friendly. The above-mentioned variables of this study are referred to and developed in this study. Sedayu also conducted a study in $2018^{2}$ on Performance Optimization Model of Hamid Rusdi Green Terminal in Malang Indonesia. The research variables are Security, safety and health, responsibility, building utility, architectural aesthetics, convenience and affordability, transport reliability, durability; frequency and density, comfort and regularity, availability and capacity of public facilities, and application of eco-friendly concepts. In 2017 Sedayu $^{3}$ also conducted research on project evaluation based on sharia construction management and green building principles. The method used is Importance Performance Analysis (IPA) and Quality Function Deployment (QFD). The research variables reviewed are assurance, responsibility, and reliability, performance, aesthetics, easiness, durability, eco-friendly, and Islamic design. Other earlier studies were also presented at the stage of preparation of research instruments.

Applied Environmental and Biological Sciences 8, no. 5 (2018): 16-23.

3 Agung Sedayu, "Project Evaluation Based On Sharia Construction Management and Green Building Principles," IPTEK Journal of Proceedings Series 3, no. 6 (2017) 


\section{B. RESULT AND DISCUSSION \\ 1. Culture and Social Aspects in Ampel Mosque}

The Ampel Mosque was built in Javanese and Arabic architectural styles and now has developed an expansion of the mosque building and the arrangement of Sunan Ampel's tomb area. The architecture and typology of the building of this mosque are influenced by the acculturation of local culture (local wisdom) and Hindu-Buddhism ${ }^{4}$. Sunan Ampel as one of Walisongo tries to spread Islam by bringing the nobleness of Islam which loves peace and harmony. This method made it easy for the people in Nusantara to embrace Islam, especially in Java. Islam as a religion that rahmatalillalamin can merge and blend with the socio-cultural that developed in a society. Islam exists as a religion to regulate the local socio-cultural life to be directed, peaceful, regular, and harmonious. This propaganda model of Sunan Ampel can be seen in the Ampel mosque building which unites a lot and there is Islamic acculturation with the social culture of the local community. The Ampel Mosque was also built taking into account the tropical environmental factors in Nusantara. Figure 1 shows the original part of the Ampel mosque. The pyramid roof with three stacks shows the symbol of God and high sanctity from the lowest level to the highest level. The arrangement of stack 3 on the roof is also shown in mosque buildings in Nusantara such as the Great Mosque of Demak, Menara Kudus Mosque, Mataram Kotagede Mosque, and Keraton Jawa mosques. The mosque building is designed to be environmentally friendly. The basic form of the roof in the form of a pyramid as a filter for heat in a tropical climate so as to make the sheltered room cool and comfortable. Roofing material in the form of clay tile or wood sheets originating from nature is also able to reduce air heat radiation and sunlight. Building wall materials in the form of clay bricks and frame construction using teak wood. The supporting material for the roof truss

\footnotetext{
${ }^{4}$ Agung Sedayu, "The priority of maintaining the reliability of sustainable construction at the Ampel Mosque Surabaya," ed. oleh P. Hajek et al., MATEC Web
}

construction is teak wood. The single tower of the mosque with the construction of a brick wall serves for the worship time at the mosque as shown in figure 1 .

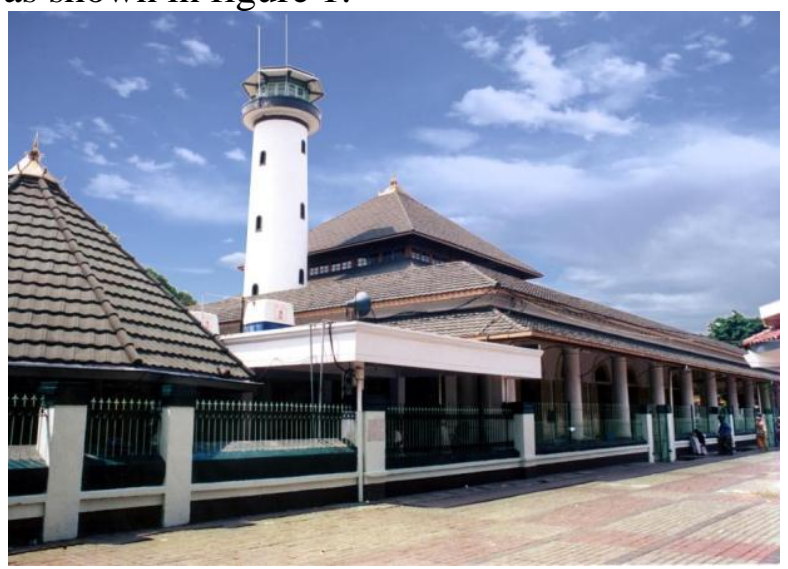

Figure1. The original part of the Ampel Mosque building

The mosque walls in the form of brick walls with a thickness of $\pm 30 \mathrm{~cm}$ to be the main support for the roof truss. The side of the building without columns so that the load from the roof is supported by the bearing wall. Figure 2 shows the original part of the building with walls and doors of the mosque. The doors and ventilation above the door with large size to facilitate the circulation of people in and out of the mosque and facilitate air circulation so as to make comfortable and cool space in the mosque. The leaves and door frames are made of teak wood material with door leaf design in the form of jalousie which also supports smooth air circulation. Air ventilation above the door using teak wood sills with leaf and flower motifs from the surrounding environment. The Ampel Mosque in its design includes natural elements which increasingly show that Islam is a rahmatalillalamin religion. The large size of the semi-circular ventilation gives a soft impression and expedites air circulation inside and outside the mosque building.

of Conferences 195 (22 Agustus 2018): 6008, https://doi.org/10.1051/matecconf/201819506008. 


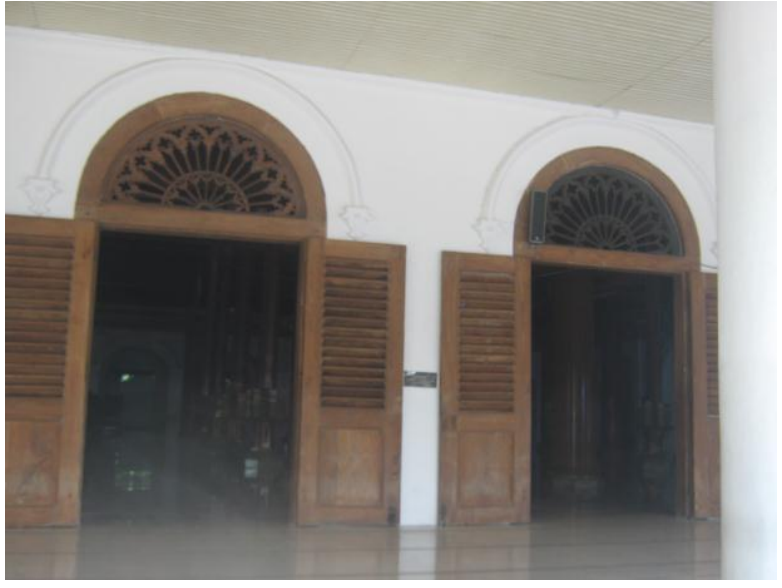

Figure 2. Large size doors and vents for good air circulation

The Ampel mosque area until now has become a religious tourism destination for visitors from domestics and foreign. Every day visitors make a pilgrimage to the tomb of Sunan Ampel and family in this mosque area. Besides that, visitors worship and do religious activities at the Ampel mosque. The Ampel Mosque is a center of various public and social activities because they come from different and diverse places. Around the Ampel Mosque area is also full of commercial areas to meet the shopping needs of visitors. The surrounding area of Ampel mosque is a dense area of settlements, retail, and shopping stands. This condition has motivated and encouraged the strengthening of ties of friendship between fellow Muslims (Ukhuwah Islamiyah) and surrounding communities with diverse backgrounds. Ampel mosque presence also supports economic growth in the surrounding area. Figure 3 shows the original Ampel Mosque building section with the foreground in the form of a circulation path for visitors coming on pilgrimage every day. Since it was founded until now the Ampel Mosque and its supporting facilities have been developed with the expansion of the mosque's land area, the addition of mosque supporting facilities, and the physical development of the mosque building.

Figure 4 is a relatively original construction of Ampel mosque building using a frame system that uses teak wood material. Teak wood is a material that is widely available in the
Ampel mosque area at that time. The physical and non-physical elements attempt to be integrated by Sunan Ampel in this mosque. One of the physical elements included in the mosque is the use of local materials in the form of teak wood.

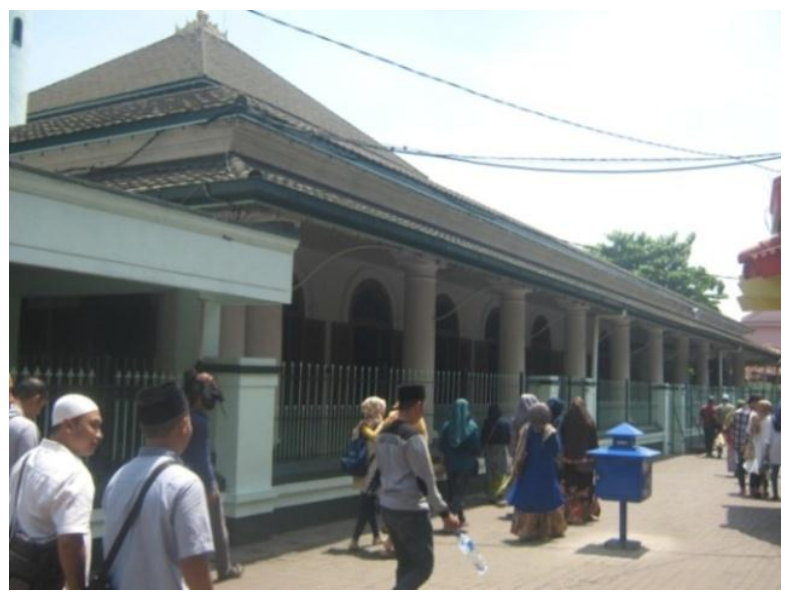

Figure 3. The original part of the building with circulation for visitors

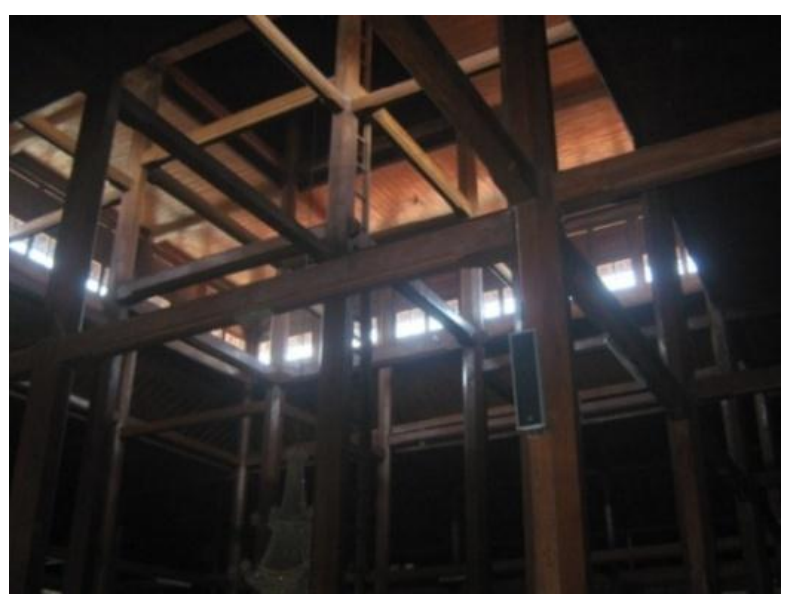

Figure 4. The original construction of the Ampel mosque building with teak wood frame

This expansion and development aim to ensure the comfort, safety, and convenience of visitors when visiting the Ampel mosque. Figure 5 is the construction of the Ampel mosque building which includes a new development area by applying reinforced concrete frame systems. The building construction system and materials used are new, but the philosophical and symbolic elements are still in harmony with the old (original) building. 


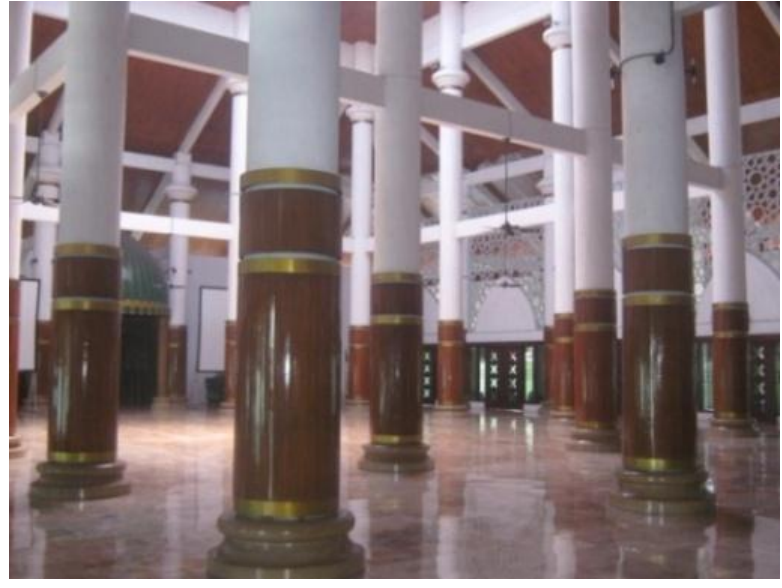

Figure 5. The new construction of the Ampel Mosque Building with reinforced concrete frames

The acculturation between Islam and socioculture in Nusantara produces almost the same typology of mosque buildings. The typology of the Ampel mosque Surabaya has similarities with other mosques in the land of Java. The same assessment with the Great Mosque of Demak which still maintains an overall appreciation of the values of holiness in the concept of symbols that is as the highest level of a human spiritual journey to human beings or perfect human beings. The roof structure of the three-tiered mosque (see Figure 6) is a description of the stages of attaining human life from those arranged from below and towards one point to the top which is called mastaka ${ }^{5}$. The interpretation of the form of a three-tiered roof is interpreted with the same understanding even though several opinions mention it in a different form of utterance. At a level that is often heard in its connotative sense gives meaning to Iman, Islam, and Ihsan. The Great Mosque of Demak became one of the works of Islamic architecture which were born from the interaction between the basic principles of Islam with elements of local wisdom when it was nuanced in the Majapahit empire.

5 Elisya Wulandari, "Simbolisme Masjid Agung Demak," in Seminar Ikatan Peneliti Lingkungan Binaan

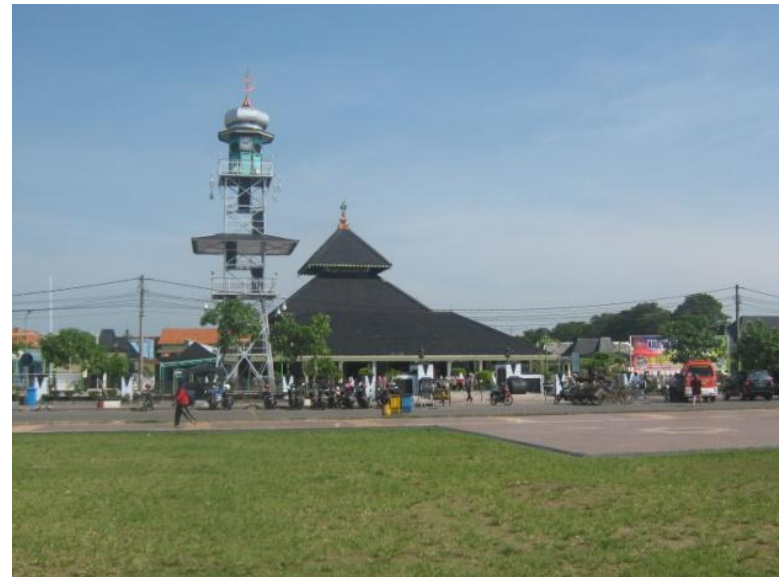

Figure 6. The part of front facade in Great Mosque of Demak

The Great Mosque of Demak in Central Java, which was founded by Raden Patah (King of Demak) in 1474 implemented a building system similar to the Ampel Mosque. The technical system of the building is in the form of a teak wood frame structure and brick bearing walls. The indoor air circulation system is facilitated by wide doors and windows and using teak wood sills. The roof covering of the mosque uses teak wood sheets which are arranged in a stairway. Striking differences in the shape of the minarets that apply steel frames that have been built during the era of modern architecture (1932). The layout of the mosque on the front faces the square which is one part of the Islamic city spatial concept which is disseminated and applied by the saints (wali). The Great Mosque of Demak became the great mosque of the kingdom of Demak and the center of the spread of Islam by Walisongo. Around the Great Mosque of Demak, there is also the tomb of the kings of Demak with families and local scholars. The uniqueness of the main part of the mosque is the presence of 4 main pillars which in Javanese are called 4 soko, one of which is soko tatal (see Figure 7). Soko means the main pillar, and Tatal has the meaning of broken wood. The four pillars are assistance from four Walisongo. Three pillars in the form of large

Indonesia (Ikatan Peneliti Lingkungan Binaan Indonesia, 2017), A055-062, https://doi.org/10.32315/sem.1.a055. 
teak wood are Sunan Ampel, Sunan Bonang, and Sunan Gunung Jati. While Soko Tatal is a creation of Sunan Kalijaga.

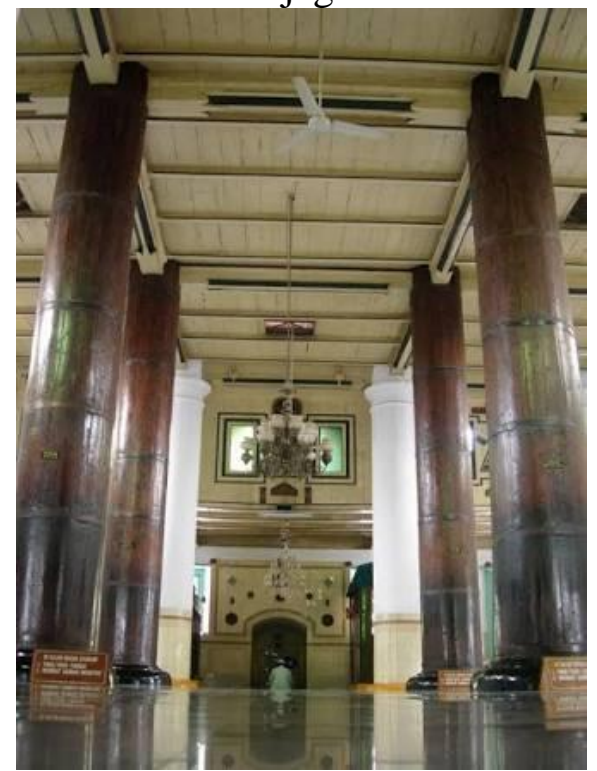

Figure 7 The main hall of the Great Mosque of Demak with four main pillars (soko)

The same typology is also found in the Menara Kudus Mosque (see Figure 8). But there is a uniqueness and difference in this mosque compared to the Ampel mosque. Tolerance to religious, social and cultural diversity is also demonstrated in the Menara Kudus mosque.

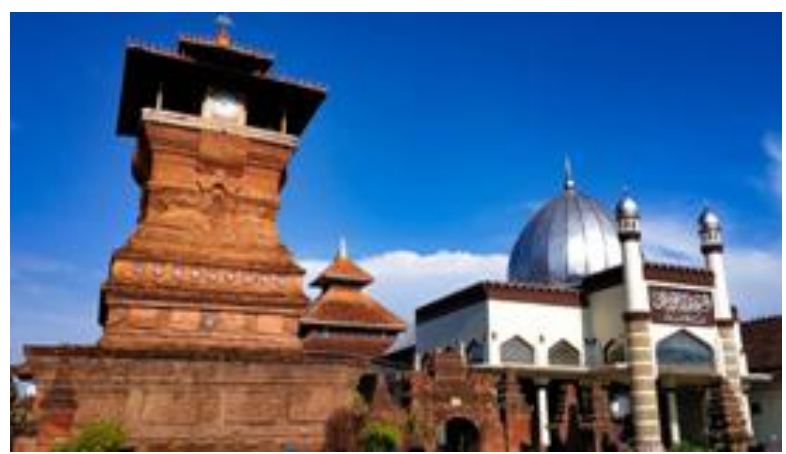

Figure 8 The front view of the Menara

Kudus mosque

This mosque became proof of tolerance from the times between Muslims and other religions at that time, namely Hinduism and Buddhism. This can be seen from the cultural acculturation and architectural style of the mosque tower

\footnotetext{
${ }^{6}$ Moh Rosyid, "The Kauman area of Menara Kudus Mosque as a Cultural Heritage: Notes on the Policy of
}

which has Javanese Hindu style, where at the time Sunan Kudus preached to the majority of the community around the mosque who adhered to Hinduism, Buddhism, and animism. The minarets and some parts of the mosque in the form of a gate (gapura) are similar to building temples to become a medium for propagation for Sunan Kudus so that followers of other religions are interested in learning and eventually embracing Islam. Sunan Kudus tried to make it known that Islam is a religion full of peace, upholding tolerance, and strengthening harmony among human beings. At the beginning of its construction, Sunan Kudus laid the first stone using stone from Baitul Maqdis (Aqsa Mosque) in Palestine. Therefore this mosque was later named Al-Aqsa Mosque Manarat Qudus. At the back of the mosque's mihrab there is the tomb of Sunan Kudus and families, and the students of Sunan Kudus who helped spread the religion of Islam in the Kudus area and beyond. Unlike the Great Mosque of Demak, which is integrated directly with the town square, the Menara Kudus Mosque is located quite far from the Kudus city square. The mosque with its area in the form of Kauman village was designated as a cultural heritage of Islam by the Kudus Regency government ${ }^{6}$. The element of tolerance in the Menara Kudus mosque also appears in the inner room, namely the gate that uses brick material with Hindu and Buddhist architecture (see Figure 9).

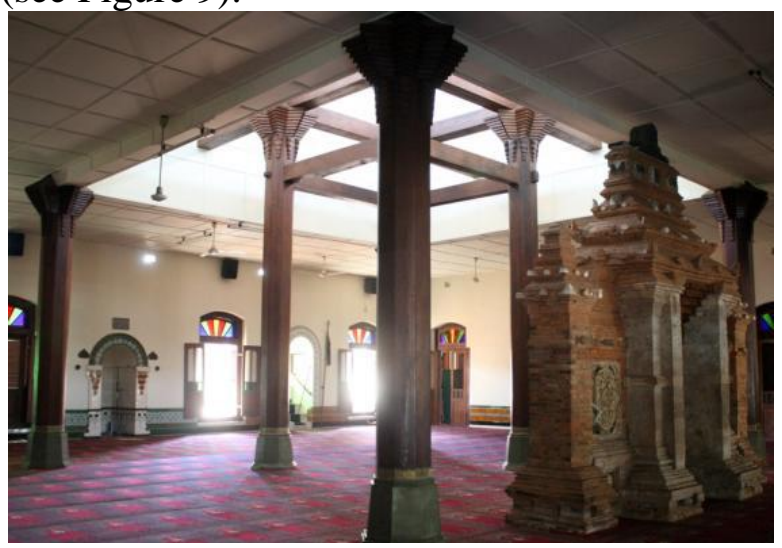

Figure 9 Gapura in the main hall of Menara Kudus mosque

the Kudus Regency Government," PURBAWIDYA: Jurnal Penelitian dan Pengembangan Arkeologi 7, no. 1 (2018): 89-110, https://doi.org/10.24164/pw.v7i1.253. 
The gate is called gapura in Java especially in Kudus. The front of the building is the result of the development in the form of a dome roof and reinforced concrete construction. The construction system for other building components has similarities with the Ampel Mosque, namely the construction of the teak wood frame and brick bearing wall supporting the roof frame. The same thing is shown in the architecture of the mosque of Mataram Kotagede Yogyakarta which combines two cultural elements namely Islam and Hinduism because at that time most people still adhered to the teachings of Hinduism. The building which is influenced by Hindu culture is a gate called Paduraksa with carved frames. At the top of the mosque's roof there is a Mustaka or Mastaka. In this mosque is seen a mace that has a large size with a leaf-shaped ornament decoration. The club's crest on the top of the mosque roof is a symbol of Allah's Oneness. The mosque building is dominant including the Javanese building because it is in the form of a pyramid. The characteristics of the pyramid building are the pyramid-shaped roof and the core and porch.

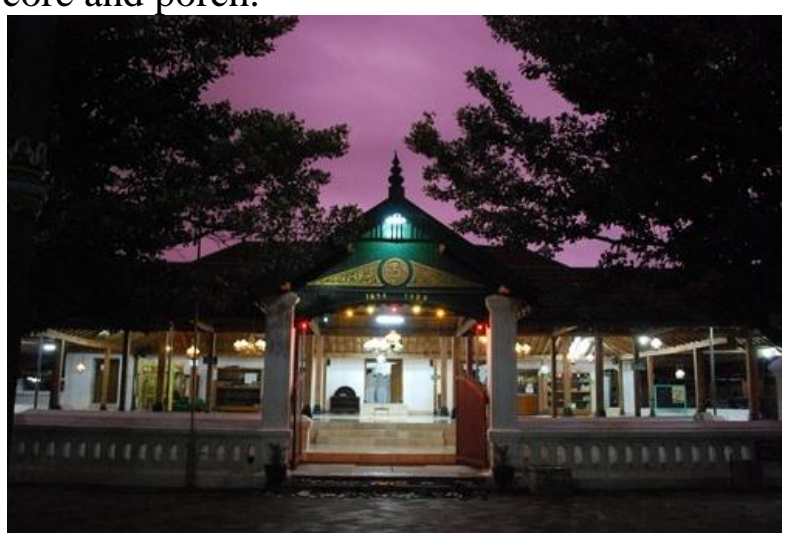

Figure 10 The nuance of the front of the Kotagede mosque at night

Figure 10 is the mass structure of the Kotagede Mosque building, and Figure 11 is the mosque's gate (gapura) which is influenced by Hindu architecture. The Kotagede Mataram Mosque or also called the Mataram Kotagede

7 Hamim Thohari, "Masjid Gede Mataram di Kotagede, Destinasi Wisata Religi Muslim Bernilai Sejarah Tinggi," Tribun News, diakses 16 Juli 2018, https://www.tribunnews.com/travel/2015/05/16/masjid-
Mosque is the oldest mosque in Yogyakarta built the first time by Panembahan Senopati (Sutawijaya) since 1587 during the Islamic Mataram empire ${ }^{7}$. In 1640 the mosque was developed by Sultan Agung who was assisted by local people who were then still Hindu and Buddhist. In this mosque area, there is also the tomb of the first Islamic Mataram king that Panembahan Senopati (Sutawijaya) and his family. Sultan Hadiwijaya (Jaka Tingkir) and Ki Ageng Archery were also buried in this area.

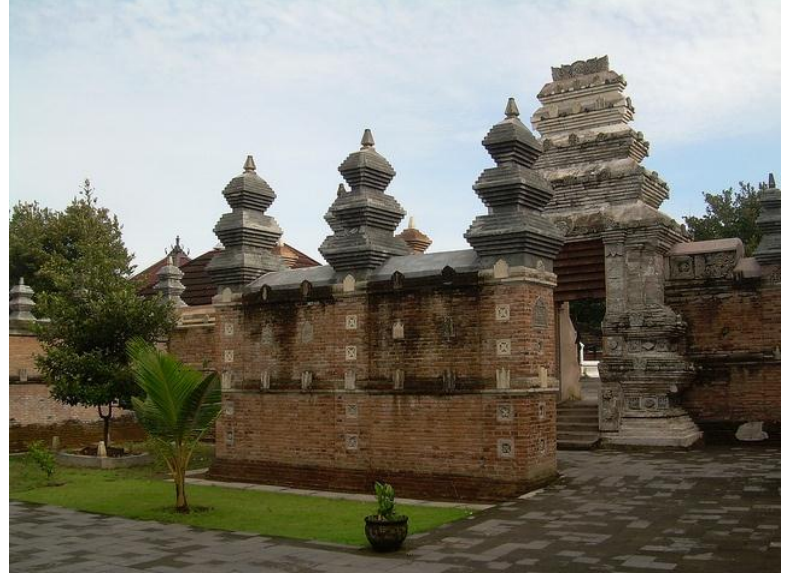

Figure 11 Entrance gate of the area in the Mataram Kotagede mosque

The mosque building materials come from the surrounding area with stone materials for foundations, bricks for walls, wood for sills and roof frames, and clay tiles. Existing structural models can adapt to Indonesia's tropical conditions, especially the Java region. The wall of the building besides serves as a filler (a blanket of the building) also as a bearing wall (bearing wall) load from the roof with a thickness of $\pm 40 \mathrm{~cm}$.

\section{Preparation of Research Instruments}

The conceptual framework of this study refers to the Performance-Based Design of Buildings (PeBBu), Final Domain Report CIBdf (Spekkink, 2005) ${ }^{8}$ which gives the concept of the quality of building maintenance such as based on performance by considering the balance between the technical aspects of the

gede-mataram-di-kotagede-destinasi-wisata-religimuslim-bernilai-sejarah-tinggi.

8 Dik Spekkink, Performance Based Design of Buildings (Rotterdam: Performance Based Building, 2005). 
building includes major facilities and support with the user needs (social-culture aspects). There is compatibility between the technical aspects and social-culture aspects by the user. The research instruments are questionnaires distributed to a number of respondents. Research respondents consist of pilgrims who often use the mosque as a place of worship. This research tries to combine social aspects with the technical aspects of building components. Social aspects are derived from respondents and technical aspect include building components that have influence in building maintenance. The mosques pilgrims are usually people in the neighborhood around the Ampel mosque so know the development of the mosque, especially the physical component of the building. The research instrument consisted of several building maintenance variables that were cited in previous research. Several previous studies which have been used in the preparation of research instruments are Sedayu $(2016)^{9}$ conducting research on evaluation of green building performance of boarding school with Importance-Performance Analysis (IPA) method and Quality Function Deployment (QFD). Research variables obtained by Sustainable, Earth-friendly, and High-performance building. Kusumawardani $(2016)^{10}$ conducted a study on the component description on the facade element of the great mosque of Jami 'Malang. The method used is observation, qualitative, descriptive. The research variables obtained are form, dimension, material, color, texture. This

9 A. Sedayu, "Performance Evaluation of Green Building in Islamic Boarding School," in IPLBI Scientific Meeting (Malang, 2016).

10 R. P. Kusumawardhani, N. Suryasari, dan A. Antariksa, "Komponen pada Elemen Fasade Masjid Agung Jami'Malang Periode 1910, 1940, dan 2016," Jurnal Mahasiswa Jurusan Arsitektur 4, no. 4 (2016).

11 J. Abimaje dan A. N. Baba, "An assessment of timber as a sustainable building material in Nigeria," International Journal of Civil Engineering, Construction and Estate Management 1, no. 2 (2014): 39-46.

12 C. Hein et al., "Hybrid Timber Constructioncombining material properties for energy efficiency and sustainability," IABSE Symposium Report 105, no. 52 (2015): 1-10. research combines both qualitative and quantitative methods that validate each other. Abimaje et. al (2014) ${ }^{11}$ conducts research on timber assessment as a sustainable material in Nigeria. Research variables reviewed Workability, Durability, low thermal conductivity, preservative treatments, and fire retardant and afforestation. Carsten Hein (2014) ${ }^{12}$ conducts research Development of hybrid wood construction in high buildings with research variables embodied energy, low carbon, and sustainability. Muzammil (2014) ${ }^{13}$ produces research variables Flood intensity, groundwater quality, flood areas, and soil types can be developed in this study. This research develops research variables from Hasan $(2014)^{14}$ which consists of energy efficiency, energy audit and building automation system. Komalasari $(2014)^{15}$ conducted a study that became the variable reference for this study. The research topics discussed are Green Building assessment based on energy efficiency and conservation with comparison study method, modeling with software, and direct measurement. Research variables reviewed include Energy Efficiency Measure, Natural and Artificial Lighting, Ventilation, Climate Change Impact, Vertical Transportation, and Air condition system. Research belongs to Adebara et. al. (2014) ${ }^{16}$ become a reference for the development of the method that is about influence analysis of timber as building construction material with Investigated and Ranking and Quality control measures. Research variables reviewed include Domestic

13 Rizki Muzammil, “Application of Biopore Infiltration Holes as an Alternative to Minimize Flood in Ciledug Indah Housing Area I" (Jakarta, 2014).

14 Salahuddin Hasan, "Efficiency Implementation in Building," 2014.

${ }^{15}$ R. I. Komalasari, P. Purwanto, dan S. Suharyanto, "Green Building Assessment Based on Energy Efficiency and Conservation (EEC) Category at Pascasarjana B Building Diponegoro UniversitySemarang," American Journal of Energy Research 2, no. 2 (2014): 42-46.

16 S. A. Adebara et al., "Quality and Utilization of Timber Species for Building Construction in Minna, Nigeria," The Internafional Journal of Engineering and Science 3, no. 5 (2014): 46-50. 
purposes, Deforestation, Over cultivation, Poor irrigation practices, resulting in the loss of biological, Economic productivity of the land. Nurakumala (2014) ${ }^{17}$ conducted a study aimed at determining factors affecting productivity in construction projects with dynamic systems. The method used is Second data observation, Qualitative description, and Dynamic programming. The research variables that are produced include Employee, Time of execution, Cost, and Work Environment. Sugiama (2015) ${ }^{18}$ conducts research on service quality modeling on green open space or with Importance Performance Analysis (IPA) method, Quality Function Deployment (QFD), and Focus Group Discussion (FGD). The research variables include the capability filtering solid particles from the air, capacity of amelioration/improvement of urban climate, water conservation level, and environmental aesthetics. This study refers to research conducted by Sedayu $(2016)^{19}$ on Improving service and infrastructure performance with Quality Function Deployment (QFD) and Affinity diagram. The variables studied are Facilities, Convenience, Security, Safety, Cost and Management services. The research instruments are questionnaires distributed to the respondents. The measurement scale used is Likert scale consisting of,
1. Scale $1=$ Not satisfactory
2. Scale $2=$ Less satisfactory
3. Scale $3=$ Quite satisfactory
4. Scale $4=$ Satisfactory
5. Scale $5=$ Very satisfactory

The validity and reliability test of research instruments by using SPSS 20,0 program. The test was conducted on 30 people ${ }^{20}$. The validity test to know the validity of the questionnaire to the respondent. The validity test by calculating

\footnotetext{
${ }^{17}$ Arya Nurakumala, "Determination of Factors Affecting Productivity on Construction Projects With Dynamic Systems," in Proceedings of National Seminar on Technology Management XXI, 2014..

18 A. Gima. Sugiama, "The Synergistic Model of Quality Service Design of Green Open Space Asset Through QFD," Sustainable Competitive Advantage (SCA) 2, no. 1 (2013).
}

the correlation coefficient of each item with the total score. In this study, an instrument has a high validity if the correlation value above the number 0,6 . The reliability test aims to determine the level of reliability of research instruments as a means of data collection. The instrument is called reliable if the coefficient of alpha (Alpha Cronbach coefficient) is above 0,60. Determination of number of respondents using Slovin formula ${ }^{21}$. The number of the population is the congregation of mosques who know the development of Ampel mosque as much as 820 people. Then the number of respondents as much,

$$
\begin{aligned}
& n=\frac{N}{\left(1+\left(N \times e^{2}\right)\right)} \\
& \text { so be } n=\frac{820}{\left(1+\left(820 \times 0,05^{2}\right)\right)}=268,85 \approx 270
\end{aligned}
$$

With description,

$\mathrm{n}=$ Number of samples / respondents

$\mathrm{N}=$ Total population

$\mathrm{e}=$ Error rate $5 \%$

From the calculation results with the Slovin formula, the respondents used 270 persons who became the target of the distribution of questionnaires as research instruments.

\section{Analysis of Structural Equation Modeling (SEM)}

Analysis of Structural Equation Modeling (SEM) is used to determine the influence of research variables on the construction reliability of Ampel Mosque. This analysis yields a mathematical model that can predict the quality of maintenance and reliability levels of building construction in Ampel Mosque. The SEM analysis is assisted with the computer program AMOS version 2016. The model developed is a path analysis model (recursive path analysis) that can measure the direct and

19 Agung Sedayu dan Mangkoedihardjo Sarwoko, "Service Improvement of Joyoboyo Public Transport Terminal in Surabaya," Transylvanian Review Journal 24, no. 6 (2016): 403-10.

20 Sugiyono, Statistik Non Parametris untuk Penelitian (Bandung: Alfabeta, 2003).

${ }^{21}$ Thomas P. Ryan, Sample size determination and power (New Jersey: John Wiley \& Sons, 2013). 
indirect relationships between variables in the model. The SEM path diagram is shown in Figure 12.

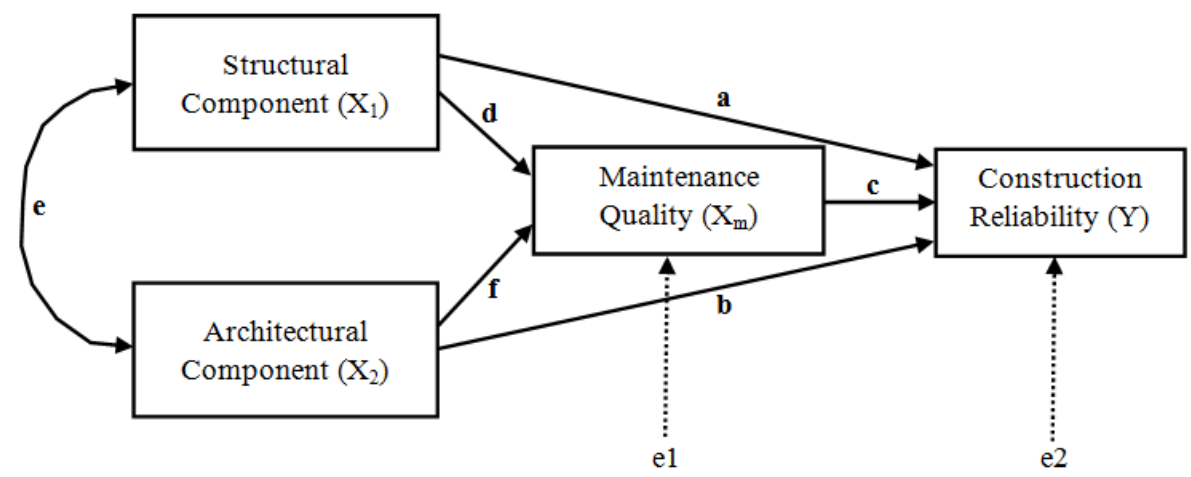

Figure 12 Model Diagram of Path Analysis SEM

From Figure 12, we can describe the equation model of the structure consisting of,

a. Structural Component $\left(\mathrm{X}_{1}\right)$ as exogenous manifest variables 1 .

b. Architectural Component $\left(\mathrm{X}_{2}\right)$ as the exogenous manifest variable 2 .

c. Maintenance Quality $\left(\mathrm{X}_{\mathrm{m}}\right)$ as an intermediate variable (moderator).

d. Construction Reliability (Y) endogenous manifest variable.

From the model in Figure 1, here is the equation model:

$\mathrm{Y}=\mathrm{aX}_{1}+\mathrm{bX}_{2}+\mathrm{cX} \mathrm{X}_{\mathrm{m}}+\mathrm{e} 1$

$\mathrm{Xm}=\mathrm{dX}_{1}+\mathrm{fX}_{2}+\mathrm{e} 2$

Before getting the model, firstly tested the normality of data wherefrom the minimum number of respondents in the model which is entirely a manifest variable at least each variable has 15 data in the form of sample or respondent $^{22}$, so $15 \times 4=60$ data. The significance test of the variable by comparing the estimated value to the probability value (p) in Maximum Likelihood Estimates. The provision is significant if the estimated value for all variables is greater than the value of the probability value (p). Next step is the convergent validity test to determine the validity of the model by comparing the value of Variance Extracted (VE) to the value of 0,5. Provided if the value of VE is smaller then the variable is declared valid with the model. For the test in Overall Model of Goodness of Fit can be seen in Table 2. Provisions of this Test if the index (in Table 2) is at the interval (cut off) $0,9<\ldots$. $\leq 1$ then the model is declared fit.

Table 1. Requirement Test in Overall Model Goodness of Fit

\begin{tabular}{lc}
\hline Goodness of Fit & Cut Off \\
\hline Normed Fit Index (NFI) & $0,90<\ldots \leq 1$ \\
Incremental Fit Index (IFI) & $0,90<\ldots \leq 1$ \\
Comparative Fit Index (CFI) & $0,90<\ldots \leq 1$ \\
Root Mean Square Error of Approximation (RMSEA) & $<1$ \\
\hline
\end{tabular}

\section{Results of Validity and Reliability Test}

22 S. Santoso, Struktural Equation Model (SEM) Konsep dan Aplikasi dengan AMOS 1 (Jakarta: Elex Media komputindo, 2011).
The results of validity and reliability test for 4 research variables in SEM model to 30 
respondents as a minimum respondent in a trial test is shown in Table 2. From Table 2 it shown that the correlation value for 4 variables above 0,6 which means that the research instrument with 4 variables is valid. Table 2 also provides information that the alpha value is above 0,6 which means the instrument is reliable. This result states that the instrument can be used at a later stage in digging and collecting data. The results of data collection with this instrument can be used in the advanced analysis of Structural Equation Modeling (SEM) analysis.

Table 2. Result of Validity and Reliability Test in Research Instrument

\begin{tabular}{clcc}
\hline No. & Research Variables & $\begin{array}{c}\text { Validity Test } \\
\text { (correlation value) }\end{array}$ & $\begin{array}{c}\text { Reliability Test } \\
\text { (alpha value) }\end{array}$ \\
\hline 1 & Structural Component $\left(\mathrm{X}_{1}\right)$ & $>0,6$ & $0,984(>0,6)$ \\
2 & Architectural Component $\left(\mathrm{X}_{2}\right)$ & $>0,6$ & $0,906(>0,6)$ \\
3 & Maintenance Quality $\left(\mathrm{X}_{\mathrm{m}}\right)$ & $>0,6$ & $0,971(>0,6)$ \\
4 & Construction Reliability $(\mathrm{Y})$ & $>0,6$ & $0,992(>0,6)$ \\
\hline
\end{tabular}

\section{4. Analysis Result of Structural Equation} Modeling (SEM)

Based on survey results and feasibility test of the previous instrument, the research variables are divided into 4 variables as in the SEM model (see Figure 1). The first stage is the data normality test where the minimum number of respondents in the model which is entirely a manifest variable at least each variable has 15 data in the form of sample or respondent, so 15 $\mathrm{x} 4=60$ data. The number of respondents is 100 people, then the requirements of normal distributed data are considered to be fulfilled. The significance test of the variable by comparing the estimated value with the probability value (p) in Maximum Likelihood Estimates as in Table 3.

Table 3. Regression Weights Variabel

\begin{tabular}{llrrrrr}
\hline \multicolumn{1}{c}{ The Relationship Between Variables } & Estimate & S.E. & C.R. & P & Significance \\
\hline $\begin{array}{l}\text { Structural Component } \\
\left(\mathrm{X}_{1}\right)\end{array}$ & $\begin{array}{l}\text { Maintenance Quality } \\
\left(\mathrm{X}_{\mathrm{m}}\right)\end{array}$ & 0,215 & 0,118 & 3,821 & 0,002 & Significant \\
$\begin{array}{l}\text { Architectural } \\
\text { Component }\left(\mathrm{X}_{2}\right)\end{array}$ & $\begin{array}{l}\text { Maintenance Quality } \\
\left(\mathrm{X}_{\mathrm{m}}\right)\end{array}$ & 0,443 & 0,207 & 8,447 & $* * *$ & Significant \\
$\begin{array}{l}\text { Structural Component } \\
\left(\mathrm{X}_{1}\right)\end{array}$ & $\begin{array}{l}\text { Construction } \\
\text { Reliability (Y) }\end{array}$ & 0,311 & 0,175 & 2,645 & 0,002 & Significant \\
$\begin{array}{l}\text { Architectural } \\
\text { Component }\left(\mathrm{X}_{2}\right)\end{array}$ & $\begin{array}{l}\text { Construction } \\
\text { Reliability (Y) }\end{array}$ & 0,505 & 0,194 & 4,373 & $* * *$ & Significant \\
$\begin{array}{l}\text { Maintenance Quality } \\
\left(\mathrm{X}_{\mathrm{m}}\right)\end{array}$ & $\begin{array}{l}\text { Construction } \\
\text { Reliability (Y) }\end{array}$ & 0,729 & 0,234 & 4,098 & $* * *$ & Significant \\
\hline
\end{tabular}

From Table 3, describe that the estimated value for all variables is greater than the value of $\mathrm{p}$. The value $\mathrm{p}=* * *$ means 0.001 . Convergent validity test to know the model correlation by comparing variance extracted value to 0,5 . Table 3 describes that the relationship between variables is Significant. 
Table 4. Standardized Regression Weights Variable

\begin{tabular}{|c|c|c|c|c|c|}
\hline \multicolumn{3}{|c|}{ The Relationship Between Variables } & \multirow{2}{*}{$\begin{array}{c}\text { Estimate } \\
0,581\end{array}$} & \multirow{3}{*}{$\begin{array}{c}\begin{array}{r}\text { Variance } \\
\text { extracted }\end{array} \\
0,265\end{array}$} & \multirow{3}{*}{$\begin{array}{c}\text { Validity } \\
\text { Valid }\end{array}$} \\
\hline $\begin{array}{l}\text { Structural Component } \\
\left(\mathrm{X}_{1}\right)\end{array}$ & $\rightarrow$ & $\begin{array}{l}\text { Maintenance Quality } \\
\left(X_{m}\right)\end{array}$ & & & \\
\hline $\begin{array}{l}\text { Architectural Component } \\
\left(\mathrm{X}_{2}\right)\end{array}$ & $\rightarrow$ & $\begin{array}{l}\text { Maintenance Quality } \\
\left(\mathrm{X}_{\mathrm{m}}\right)\end{array}$ & 0,437 & & \\
\hline $\begin{array}{l}\text { Structural Component } \\
\left(\mathrm{X}_{1}\right)\end{array}$ & $\rightarrow$ & $\begin{array}{l}\text { Construction } \\
\text { Reliability (Y) }\end{array}$ & 0,544 & & \\
\hline $\begin{array}{l}\text { Architectural Component } \\
\left(\mathrm{X}_{2}\right)\end{array}$ & $\rightarrow$ & $\begin{array}{l}\text { Construction } \\
\text { Reliability (Y) }\end{array}$ & 0,501 & 0,341 & Valid \\
\hline $\begin{array}{l}\text { Maintenance Quality } \\
\left(\mathrm{X}_{\mathrm{m}}\right)\end{array}$ & & $\begin{array}{l}\text { Construction } \\
\text { Reliability (Y) }\end{array}$ & 0,689 & & \\
\hline
\end{tabular}

The correlation that describing the influence between variables in SEM analysis is shown with a coefficient of determination. The influence model of building maintenance quality of Ampel Mosque is:

Model of the total variable influence: $\mathrm{Y}=$ $0,544 X_{1}+0,501 X_{2}+0,689 X_{m}$

Models of of intermediate variable influence (moderator): $X_{m}=0,581 X_{1}+0,437 X_{2}$

By looking at Table 4, it describes that the variance extracted value is less than 0,5 , which can be calculated as follows, -Variable of Maintenance Quality $\left(\mathrm{X}_{\mathrm{m}}\right)=$ $\frac{0,581^{2}+0,437^{2}}{2}=\frac{0,338+0,191}{2}=\frac{0,529}{2}=0,265<0,5$

-Variable of Construction Reliability $(\mathrm{Y})=$ $\frac{0,544^{2}+0,501^{2}+0,689^{2}}{3}=\frac{0,296+0,251+0,475}{3}=\frac{1,022}{3}=0,341$ $<0,5$

So from this test can be concluded that the valid model with the arrangement of its variables. Table 5 shows the estimated value between Structural Component $\left(\mathrm{X}_{1}\right)$ and Architectural Component $\left(\mathrm{X}_{2}\right)$, while Table 6 shows the estimated value between Maintenance Quality $\left(\mathrm{X}_{\mathrm{m}}\right)$ and Construction Reliability (Y). From the results of this analysis can be made path diagram model as in Figure 12.

Table 5. Correlation between $X_{1}$ with $X_{2}$

\begin{tabular}{lcc}
\hline The Relationship Between Variables & Estimate \\
\hline Structural Component $\left(\mathrm{X}_{1}\right) \leftrightarrow$ Architectural Component $\left(\mathrm{X}_{2}\right)$ & 0,317 \\
\hline
\end{tabular}

Table 6. Correlation between $\mathrm{X}_{\mathrm{m}}$ with $\mathrm{Y}$

\begin{tabular}{cc}
\hline Variables & Estimate \\
\hline Maintenance Quality $\left(\mathrm{X}_{\mathrm{m}}\right)$ & 0,816 \\
Construction Reliability $(\mathrm{Y})$ & 0,872 \\
\hline
\end{tabular}




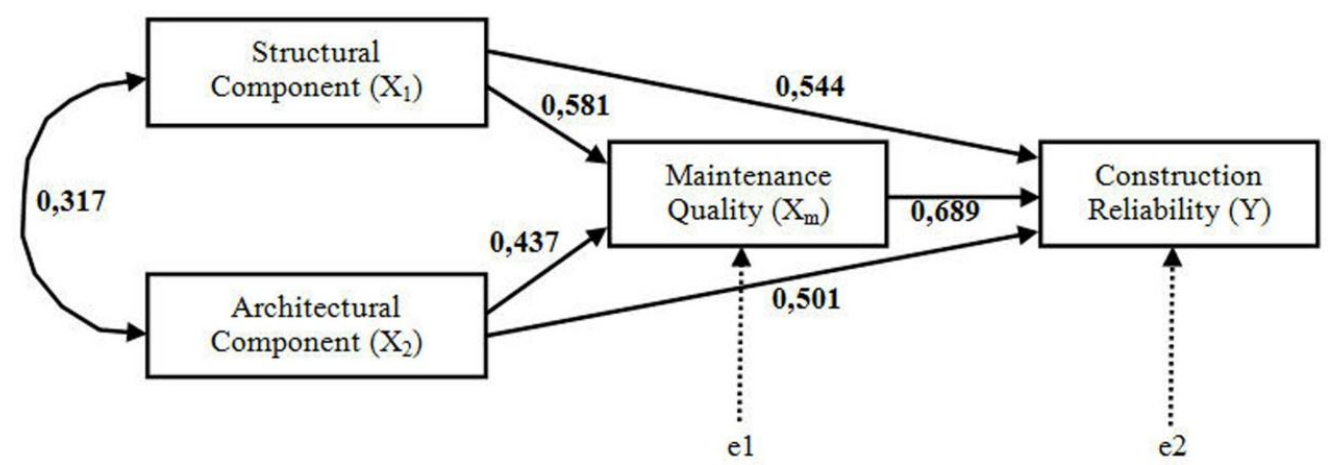

Fig. 12. The diagram model of SEM in Ampel Mosque Surabaya

The relationships between variables indicate a strong level of significance. From Table 6, it is shown that the path diagram model obtained is explained that the variability of Maintenance Quality $\left(\mathrm{X}_{\mathrm{m}}\right)$ is explained by Structural Component $\left(\mathrm{X}_{1}\right)$ and Architectural Component $\left(\mathrm{X}_{2}\right)$ of $81,6 \%$. While Construction Reliability (Y) which can be explained by the variability of Structural Component $\left(\mathrm{X}_{1}\right)$, Architectural Component $\left(\mathrm{X}_{2}\right)$, and Maintenance Quality $\left(X_{m}\right)$ of $87,2 \%$. While the model of the path diagram, obtained direct and indirect effects between variables, so it is also obtained total influence $=$ direct influence + indirect influence. It can be concluded that the influence relationship in the overall model is positive (see Table 7). The total effect between Structural Components $\left(\mathrm{X}_{1}\right)$ on Construction Reliability (Y) is the biggest among the other influences with 0,944 , while the relationship between Structural Components $\left(\mathrm{X}_{1}\right)$ on Architectural Components $\left(\mathrm{X}_{2}\right)$ has the smallest total effect with 0,317 .

Table 7. The Relationship between Services Variables

\begin{tabular}{lccc}
\hline $\begin{array}{l}\text { The Relationship } \\
\text { Between Variables }\end{array}$ & Direct Influence & Indirect Influence & $\begin{array}{c}\text { Total } \\
\text { Influence }\end{array}$ \\
\hline $\mathrm{X}_{1} \rightarrow \mathrm{Y}$ & 0,544 & $(0,581) \times(0,689)=0,400$ & 0,944 \\
$\mathrm{X}_{2} \rightarrow \mathrm{Y}$ & 0,501 & $(0,437) \times(0,689)=0,301$ & 0,802 \\
$\mathrm{X}_{\mathrm{m}} \rightarrow \mathrm{Y}$ & 0,689 & - & 0,689 \\
$\mathrm{X}_{1} \rightarrow \mathrm{X}_{\mathrm{m}}$ & 0,581 & - & 0,581 \\
$\mathrm{X}_{2} \rightarrow \mathrm{X}_{\mathrm{m}}$ & 0,437 & - & 0,437 \\
$\mathrm{X}_{1} \rightarrow \mathrm{X}_{2}$ (recursive) & 0,317 & - & 0,317 \\
\hline
\end{tabular}

\section{CONCLUSION}

The Ampel Mosque Surabaya is a historic mosque that became one of the centers of the spread of Islam in Java by Sunan Ampel. The mosque is a historic site to get attention in care and maintenance on the physical components of the building to prevent the occurrence of damage. The well-preserved and elected Ampel Mosque will become historical religious wisdom and still serve as a center of Muslim worship especially in Indonesia. The Ampel Mosque was built in Javanese and Arabic architectural styles, and now has developed an expansion of the mosque building and the arrangement of Sunan Ampel's tomb area. The architecture and typology of the building of this mosque is influenced by the acculturation of local culture (local wisdom) and HinduBuddhism.

\section{REFERENCES}

Abimaje, J., dan A. N. Baba. "An assessment of timber as a sustainable building material in Nigeria." International Journal of Civil Engineering, Construction and Estate Management 1, no. 2 (2014): 39-46.

Adebara, S. A., H. Hassan, M. B. Shittu, dan M. A. Anifowose. "Quality and Utilization 
of Timber Species for Building Construction in Minna, Nigeria." The Internafional Journal of Engineering and Science 3, no. 5 (2014): 46-50.

Hasan, Salahuddin. "Efficiency
Implementation in Building," 2014.

Hein, C., A. Lawrence, T. Snelson, A. Campbell, dan C. Heesbeen. "Hybrid Timber Construction-combining material properties for energy efficiency and sustainability." IABSE Symposium Report 105, no. 52 (2015): 1-10.

Komalasari, R. I., P. Purwanto, dan S. Suharyanto. "Green Building Assessment Based on Energy Efficiency and Conservation (EEC) Category at Pascasarjana B Building Diponegoro University-Semarang." American Journal of Energy Research 2, no. 2 (2014): 42-46.

Kusumawardhani, R. P., N. Suryasari, dan A. Antariksa. "Komponen pada Elemen Fasade Masjid Agung Jami'Malang Periode 1910, 1940, dan 2016." Jurnal Mahasiswa Jurusan Arsitektur 4, no. 4 (2016).

Muzammil, Rizki. "Application of Biopore Infiltration Holes as an Alternative to Minimize Flood in Ciledug Indah Housing Area I." Jakarta, 2014.

Nurakumala, Arya. "Determination of Factors Affecting Productivity on Construction Projects With Dynamic Systems." In Proceedings of National Seminar on Technology Management XXI, 2014.

Rosyid, Moh. "The Kauman area of Menara Kudus Mosque as a Cultural Heritage: Notes on the Policy of the Kudus Regency Government." PURBAWIDYA: Jurnal Penelitian dan Pengembangan Arkeologi 7, no. 1 (2018): 89-110. https://doi.org/10.24164/pw.v7i1.253.

Ryan, Thomas P. Sample size determination and power. New Jersey: John Wiley \& Sons, 2013.

Santoso, S. Struktural Equation Model (SEM) Konsep dan Aplikasi dengan AMOS 1. Jakarta: Elex Media komputindo, 2011.

Sedayu, A. "Performance Evaluation of Green Building in Islamic Boarding School." In IPLBI Scientific Meeting. Malang, 2016.
Sedayu, A., dan S. Mangkoedihardjo. "Performance Evaluation of Housing Contractor by Applying The Principles of Environmentally Friendly Infrastructure." International Journal of Civil Engineering and Technology 9, no. 4 (2018): 0976-6316. Sedayu, Agung. "Performance Optimization Model of Hamid Rusdi Green Terminal in Malang." Journal of Applied Environmental and Biological Sciences 8, no. 5 (2018): 1623.

. "Project Evaluation Based On Sharia Construction Management and Green Building Principles." IPTEK Journal of Proceedings Series 3, no. 6 (2017).

-. "The priority of maintaining the reliability of sustainable construction at the Ampel Mosque Surabaya." Diedit oleh P. Hajek, A.L. Han, S. Kristiawan, W.T. Chan, M.b. Ismail, B.S. Gan, R. Sriravindrarajah, dan B.A. Hidayat. MATEC Web of Conferences 195 (22 Agustus 2018): 6008. https://doi.org/10.1051/matecconf/2018195 06008.

Sedayu, Agung, dan Mangkoedihardjo Sarwoko. "Service Improvement of Joyoboyo Public Transport Terminal in Surabaya." Transylvanian Review Journal 24, no. 6 (2016): 403-10.

Spekkink, Dik. Performance Based Design of Buildings. Rotterdam: Performance Based Building, 2005.

Sugiama, A. Gima. "The Synergistic Model of Quality Service Design of Green Open Space Asset Through QFD." Sustainable Competitive Advantage (SCA) 2, no. 1 (2013).

Sugiyono. Statistik Non Parametris untuk Penelitian. Bandung: Alfabeta, 2003.

Thohari, Hamim. "Masjid Gede Mataram di Kotagede, Destinasi Wisata Religi Muslim Bernilai Sejarah Tinggi." Tribun News. Diakses $16 \quad$ Juli 2018. https://www.tribunnews.com/travel/2015/0 5/16/masjid-gede-mataram-di-kotagededestinasi-wisata-religi-muslim-bernilaisejarah-tinggi.

Wulandari, Elisya. "Simbolisme Masjid Agung Demak." In Seminar Ikatan Peneliti 
Lingkungan Binaan Indonesia, A055-062.

Indonesia,

2017.

Ikatan Peneliti Lingkungan Binaan

https://doi.org/10.32315/sem.1.a055. 